\title{
Gut associated lymphoid tissue: a morphological and immunocytochemical study of the human appendix
}

\author{
JO SPENCER, TERESA FINN, AND P G ISAACSON \\ From the Department of Morbid Anatomy, University College London School of Medicine, London
}

SUMMARY Gut associated lymphoid tissue in 15 normal appendices has been characterised in tissue sections using both morphological criteria and immunocytochemical techniques. A panel of monoclonal and polyclonal antibodies was used including antibodies to B-cells, T-cells, macrophages, HLA DR and immunoglobulins. The lymphoid tissue in the appendix was shown to bear a strong resemblance to that in lymph nodes with the exception of the region where the appendix follicles associate with the dome epithelium, which has no lymph node equivalent. This zone of cells between the lymphoid follicles and the dome epithelium termed the 'mixed cell zone' has been shown to contain an abundance of HLA DR-bearing cells, some of which have irregular nuclear morphology and resemble follicle centre cells. These cells were seen to extend into the epithelium of the dome but not the crypts. Using a monoclonal anti-B-cell antibody a population of B-cells was detected in the equivalent areas of mixed cell zone and epithelium and quantitative studies showed that these intraepithelial B-cells comprised approximately 4-5\% of the cells in the epithelium. The mixed cell zone was also seen to contain T-cells, S-100 protein-containing macrophages and occasional lysozyme-containing macrophages. Plasma cells were rarely seen in this area.

The last two decades have seen major advances in the understanding of the structure and function of gut associated lymphoid tissue and the mucosaassociated lymphoid tissue of other sites. ${ }^{1}$ These advances have been based largely on experimental work in animals and direct extrapolation from animal studies to man has provided a basis for the understanding of human gastrointestinal immunity. It is not possible to justify this extrapolation, however, because directly comparable experiments on different species such as rats and sheep for example are often not possible and the extent of species variability is as yet unknown. Studies of normal human gut associated lymphoid tissue have tended to relate to intraepithelial lymphocytes ${ }^{2}$ and lamina propria plasma cells and macrophages, ${ }^{34}$ whereas the cells which form the lymphoid follicles in the gut have remained neglected in comparison. Peripheral lymphoid tissue, however, has been the subject of thorough morphological ${ }^{56}$ and more recently immunohistochemical investigation. ${ }^{78}$

Address for correspondence: Professor P G Isaacson, Department of Morbid Anatomy, University College London School of Medicine, University Street. London, WC1E 6JJ.

Received for publication 15 August 1984
These studies largely carried out by pathologists attempting to explain features of malignant lymphoma revealed the close similarity between lymphoma and reactive lymphoid tissue. Gastrointestinal lymphoma is known to have several features which distinguish it from that occurring in peripheral lymph nodes and this study was embarked upon in the hope that the understanding of normal gut associated lymphoid tissue will help to account for these differences. Appendix tissue was used because of its ready availability and rich content of gutassociated lymphoid tissue.

\section{Methods}

\section{TISSUES}

Fifteen fresh human appendices were obtained from either right hemicolectomy specimens, from appendicectomies carried out during laparotomies for other disorders, or from cases of acute appendicitis. In the latter case tissue for study was taken as far as possible from the site of inflammation which was always minimal. The appendices were sectioned transversely. Tissue for paraffin embedding was fixed in acid formalin ${ }^{9}$ while other tissue was snap 
frozen in liquid nitrogen for the preparation of cryostat sections. Paraffin embedded and frozen blocks were selected for immunocytochemistry after morphological study of haematoxylin and eosin $(\mathrm{H}$ \& E) stained sections.

\section{IMMUNOCYTOCHEMISTRY}

The antibodies used, their source and reactivity are shown in Table 1. In summary, paraffin sections were stained with polyclonal antibodies to all immunoglobulin (Ig) heavy chains, lysozyme, S-100 protein and a monoclonal antibody to HLA DR. Cryostat sections were stained with polyclonal antibodies to IgM and IgD and monoclonal antibodies reactive with all B-cells, T-cells and T-helper and suppressor subsets.

Cryostat sections of $6 \mu \mathrm{m}$ thickness were dried at $-20^{\circ} \mathrm{C}$, then fixed in acetone for 30 minutes immediately before staining. With the polyclonal primary antisera the peroxidase anti-peroxidase technique was used and with the monoclonal antibodies a double layer technique was used involving a rabbit antimouse secondary antiserum conjugated to horseradish peroxidase. The precise details of these methods have been published elsewhere. ${ }^{10}$ Peroxidase activity was shown using the $3^{\prime}, 3^{\prime}$-diaminobenzidine reagent as described by Graham and Karnovsky. ${ }^{11}$ Nuclei were counter-stained with haematoxylin.

Dewaxed and rehydrated paraffin sections of $3 \mu \mathrm{m}$ thickness were stained using the immunoperoxide techniques described above.

\section{QUANTITATIVE STUDIES OF INTRAEPITHELIAL}

\section{LYMPHOCYTES}

Quantitative studies of intraepithelial lymphocytes were carried out on sections stained with the anti-T-cell and anti-B-cell monoclonal antibodies and the antiserum to $\mathrm{IgD}$. The number of cells recognised by each of these antisera was counted using $\times 40$ objective and expressed as a percentage of the number of cells, both stained and unstained, in the same area. For each antiserum approximately 150 dome cells were counted in each of three repeat slides. This was done for each appendix studied.

\section{MORPHOLOGICAL OBSERVATIONS}

All appendices studied showed the characteristic prominent mucosal lymphoid nodules separated by areas of lamina propria with few small lymphocytes (Fig. 1). The latter, designated the crypt area, was populated almost entirely by mature plasma cells together with macrophages which were concentrated immediately beneath the epithelium (Fig. $2 a$ ). Each mucosal lymphoid nodule consisted of a prominent follicle centre (Fig. 2 b) surrounded by a mantle of small lymphocytes (Fig. 2c) which was more marked on the mucosal aspect and which merged with the broader zone of lymphoid tissue which abutted on the muscularis mucosae. This broader zone contained the high endothelial venules. The lamina propria between the follicular mantle and the surface epithelium contained a mixed population of lymphoreticular cells which was quite distinct from the adjacent plasma cell-rich lamina propria and was accordingly designated the mixed cell zone $\mathrm{z}^{12}$ (Fig. 2d). Within the mixed cell zone were small lymphocytes and also some larger lymphoid cells containing nuclei with irregular outlines. These larger cells bore a close resemblance to follicle centre cells (centrocytes). Also present were numerous macrophages. Intraepithelial lymphocytes could be recognised throughout the surface epithelium of the appendix (Fig. 3a). Those intraepithelial lymphocytes within the epithelium of the crypts were small with dense round nuclei (Fig. 3b). In the epithelium related to the mixed cell zone, the so-called dome epithelium, the density of in-

Table 1 Details of antibodies used

\begin{tabular}{|c|c|c|c|}
\hline & Anti-human antiserum & Source & Specificity \\
\hline \multirow[t]{7}{*}{ Rabbit polyclonal antisera } & Anti-IgA & Dakopatts & Immunoglobulin $\alpha$-chains \\
\hline & Anti-IgG & ," & $\gamma$-chains \\
\hline & Anti-IgM & , & $\mu$-chains \\
\hline & Anti-IgE & , & $\xi$-chains \\
\hline & Anti-IgD & , & $\delta$-chains \\
\hline & Lysozyme &, & Lysozyme \\
\hline & S-100 protein & & $\mathrm{S}-100$ brain protein \\
\hline \multirow{5}{*}{ Mouse monoclonal antibodies } & IB5 & ${ }^{*}$ ICRF & HLA DR antigens \\
\hline & Anti-B-cells & Dakopatts & All B-cells \\
\hline & UCH-T1 & **ICRF & All T-cells \\
\hline & UCH-T4 & ${ }^{* *}$ ICRF & Suppressor T-cells \\
\hline & Leu $3 a$ & Beckton Dickinson & Helper T-cells \\
\hline
\end{tabular}

Antisera kindly provided by *Dr T Adams and ** Dr P Beverley, Imperial Cancer Research Fund. 


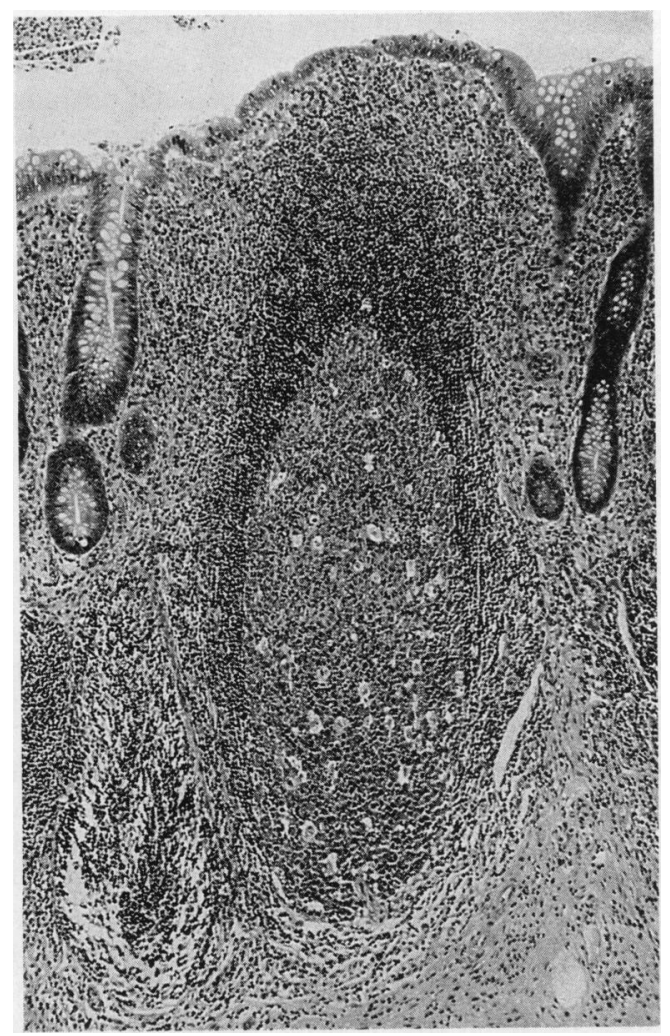

Fig. 1 Lymphoid nodule in appendiceal mucosa. $A$ prominent reactive follicle centre is surrounded by a mantle of small lymphocytes which merge with the mixed cell zone beneath the dome epithelium. On either side of the lymphoid nodule the lamina propria is populated principally by plasma cells. The T-cell area below the follicle centre is poorly developed in this section. Haematoxylin and eosin $\times 100$.

traepithelial lymphocytes was increased. Some of the lymphocytes in this region were larger and contained heterochromatic nuclei with irregular outlines again resembling centrocytes (Fig. 3c).

\section{IMMUNOHISTOCHEMICAL OBSERVATIONS}

Most of the plasma cells in the crypt area of the lamina propria contained cytoplasmic $\operatorname{IgA}$ or $\operatorname{IgG}$ with fewer cells containing IgM or IgE. Macrophages in this region contained lysozyme and HLA DR antigens. Some of these macrophages were positive when stained for S-100 protein.

The follicle centres showed strong network staining of extra-cellular Ig of all classes and surface immunoglobulin could not be shown on the follicle centre cells. The follicle centre cells and mantle zone cells were strongly positive with the anti-B-cell antiserum, the latter also showing strong staining for SIgD and SIgM.

The small lymphocytes surrounding the follicles together with those of the broad zone impinging on the muscularis mucosae were strongly reactive with the pan T-cell antibody (Fig. 4). T-cells could also be identified within the follicle centres and the mantle, the former being almost exclusively of T-helper phenotype. In the T-cell areas the helper: suppressor T-cell ratio was approximately $8: 1$. Numerous HLA DR-positive macrophages were present in these T-cell areas. Some cells in the T-cell area were recognised by the anti-S-100 antiserum, but unlike those beneath the epithelium, these lacked obvious cytoplasmic processes and resembled small lymphocytes (Fig. 5a).

The B-cell nature of many of the cells in the mixed cell zone was evident from their reactivity with the anti-B-cell antiserum (Fig. 6). B-cells with SIgD, presumably mantle cells, were seen extending into this region, and many cells with SIgM were seen to be present. Only occasional cells with cytoplasmic immunoglobulin were seen in the mixed cell zone. This zone contained an abundance of HLA DR bearing cells, including the cells with centrocytic morphology observed previously in haematoxylin and eosin sections (Fig. 7). It is probable that these cells were among those identified by the anti-B-cell antibody in frozen sections. Macrophages with obvious cytoplasmic processes containing S-100 protein (Fig. 5b) and helper and suppressor T-cells were also present in the mixed cell zone (Fig. 4).

Intraepithelial T-cells of T-suppressor phenotype were present in the dome and the crypt epithelium as expected. ${ }^{2}$ In addition to the T-cells, however, a population of B-cells was observed in the epithelium of the dome above the mixed cell zone but not in the epithelium of the crypts (Fig. 6). These B-cells were recognised in frozen sections by staining with the anti-B-cell antiserum. They were not consistently detectable by surface or cytoplasmic immunoglobulin, probably due to background staining of the immunoglobulin, bound to secretory component on the epithelial cells. In addition to the small, round intraepithelial lymphocytes seen throughout the gut, intraepithelial lymphocytes with irregular nuclear morphology were observed in the dome epithelium in paraffin sections and they were shown using immunohistochemistry to bear HLA DR antigens (Fig. 7a). These cells probably correspond to those recognised by the anti-B-cell antibody in frozen sections.

In order to compare the populations of intraepithelial lymphocytes in the dome and crypt regions, the cells recognised by the antisera UCH T1, anti-IgD and anti-B-cell were counted and express- 


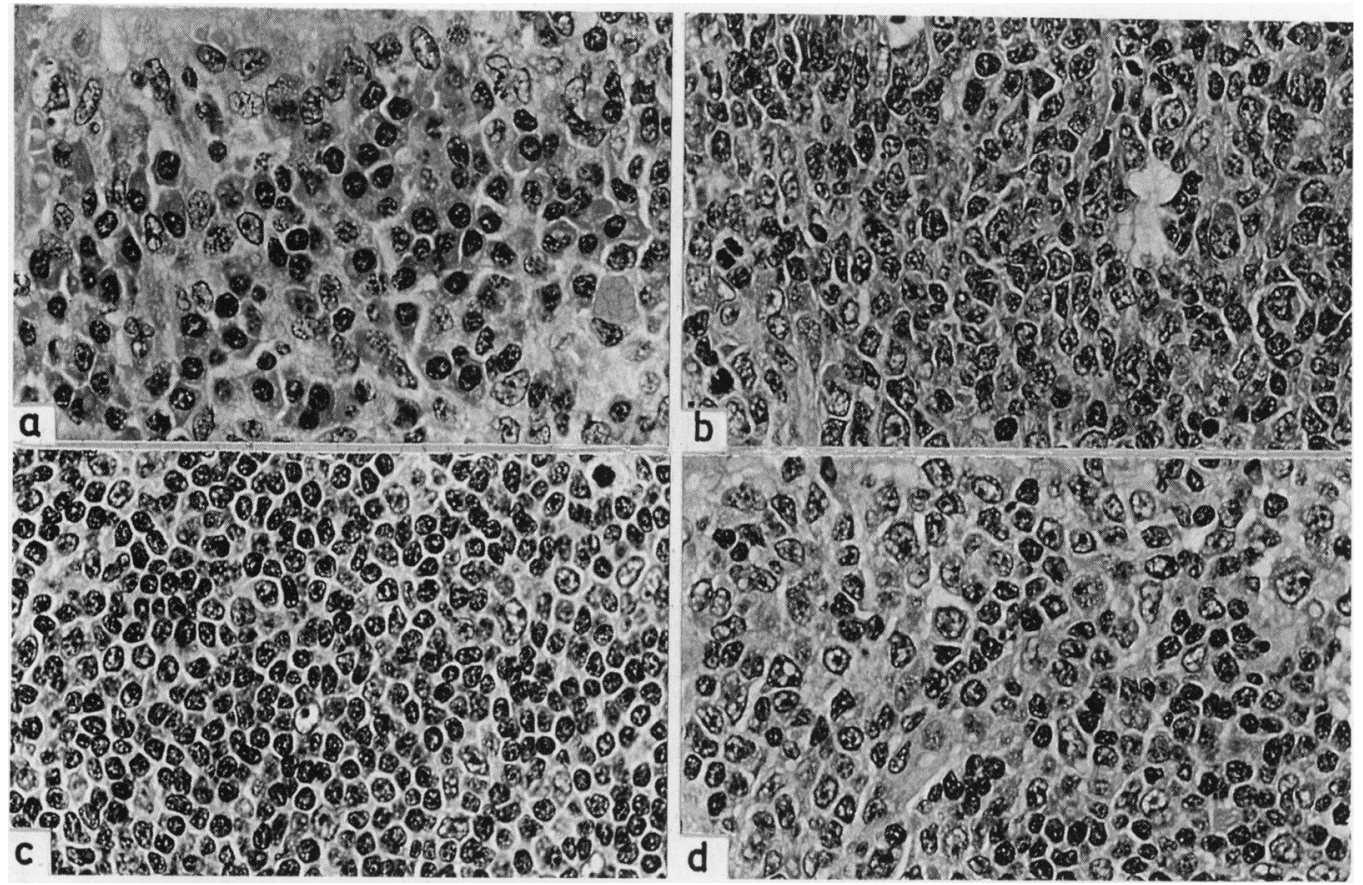

Fig. 2 Cytological detail of the different areas illustrated in Fig. 1.

(a) Lamina propria of the crypt area showing plasma cells with macrophages concentrated beneath the surface epthelium at upperleft.

(b) Follicle centre showing the typical mixture of centrocytes, centroblasts and macrophages.

(c) Mantle zone consisting principally of small lymphocytes.

(d) Mixed cell zone beneath the dome epithelium in which many lymphocytes show similar nuclear morphology to those

illustrated in $b$. Haematoxylin and eosin $\times 1000$.

ed as a percentage of the number of unstained cells (both epithelial and lymphoid) in the same area. The results are shown in Table 2 . It can be seen that the number of B-cells constantly exceeded the number of mantle cells (those with IgD). The presence of mantle cells in the epithelium on occasions was probably due to tissue damage. T-cells were sometimes seen to vary in number between the dome and the crypt epithelium but there was no consistent pattern of distribution.

An additional finding was reactivity of some dome epithelial cells for HLA DR in contrast to constantly HLA DR-negative epithelium in the crypt areas (Fig. 8). This was true of half of the appendices studied. The epithelia of the rest were HLA DR-negative.

Our observations are summarised in Table 3.

\section{Discussion}

While the appendix was chosen for this study for reasons of convenience, it is possible that appen- diceal lymphoid tissue is not representative of that elsewhere in the gut. Preliminary studies of jejunal, ileal and colonic gut associated lymphoid tissue have, however, resulted in similar findings (unpublished observations). Our morphological and immunocytochemical observations of gut associated

Table 2 Numbers of immunostained cells per hundred unstained cells in the same area of epithelium

\begin{tabular}{|c|c|c|c|c|c|c|c|}
\hline \multirow[b]{2}{*}{ Patient } & \multicolumn{2}{|c|}{ UCH TI } & \multicolumn{2}{|c|}{$I g D$} & \multicolumn{2}{|c|}{$B$ cells } & \multirow{2}{*}{$\begin{array}{l}B \text { cells } \\
\text { slgD+ } \\
\text { cells } \\
\text { Dome }\end{array}$} \\
\hline & Dome & Crypt & Dome & Crypt & Dome & Crypt & \\
\hline 1 & $5 \cdot 5$ & $2 \cdot 5$ & $2 \cdot 3$ & 0 & $9 \cdot 5$ & 0 & $7 \cdot 2$ \\
\hline 2 & $16 \cdot 3$ & $3 \cdot 4$ & 0.3 & 0 & $5 \cdot 0$ & 0 & $4 \cdot 7$ \\
\hline 3 & $12 \cdot 3$ & $6 \cdot 3$ & 0.9 & 0.5 & $6 \cdot 7$ & 0 & $5 \cdot 8$ \\
\hline 4 & $3 \cdot 1$ & $3 \cdot 5$ & $7 \cdot 7$ & ND & $14 \cdot 0$ & 0 & $6 \cdot 3$ \\
\hline 5 & $15 \cdot 1$ & $1 \cdot 6$ & 0.5 & 0 & 4.9 & 0 & $4 \cdot 4$ \\
\hline 6 & $7 \cdot 8$ & $4 \cdot 1$ & 0 & 0 & $4 \cdot 4$ & 0 & $4 \cdot 4$ \\
\hline 7 & $3 \cdot 3$ & $5 \cdot 8$ & 0 & 0 & $2 \cdot 4$ & 0.4 & $2 \cdot 4$ \\
\hline 8 & $16 \cdot 2$ & $4 \cdot 8$ & $2 \cdot 8$ & 0 & $3 \cdot 8$ & 0 & $1 \cdot 0$ \\
\hline 9 & $10 \cdot 3$ & $4 \cdot 8$ & 0.4 & 0 & $8 \cdot 5$ & $1 \cdot 0$ & $8 \cdot 1$ \\
\hline 10 & 8.9 & $3 \cdot 5$ & 0.7 & 0 & $3 \cdot 0$ & 0.2 & $2 \cdot 3$ \\
\hline
\end{tabular}



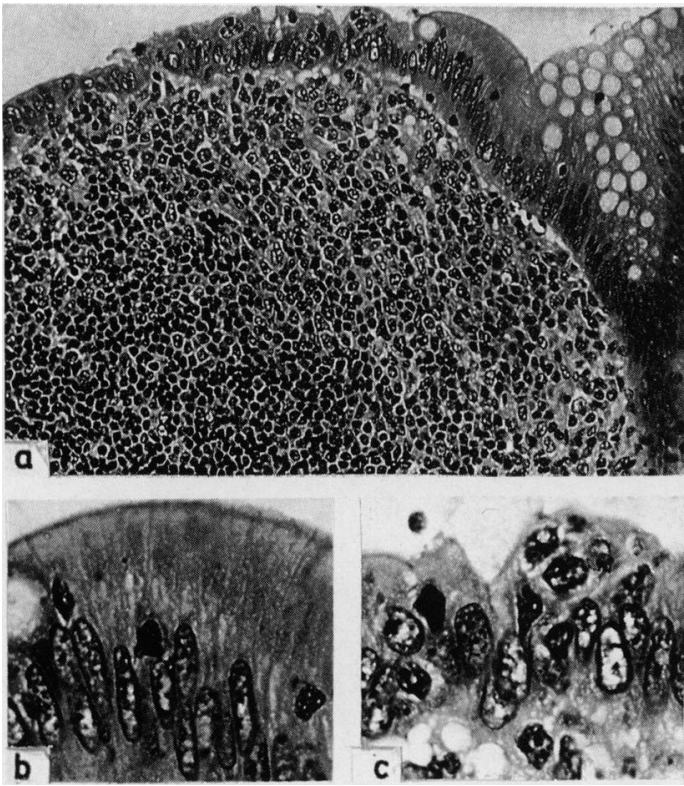

Fig. 3

(a) Dome epithelium containing numerous intra-epithelial lymphocytes merging with crypt epithelium at right.

(b) Detail of crypt epithelium showing scattered intraepithelial lymphocytes with densely staining model.

(c) Dome epithelium showing intra-epithelial lymphocytes larger than those in (b) and with nuclei resembling centrocytes. Haematoxylin and eosin $(a) \times 250$, (b) and (c) $\times 1250$.

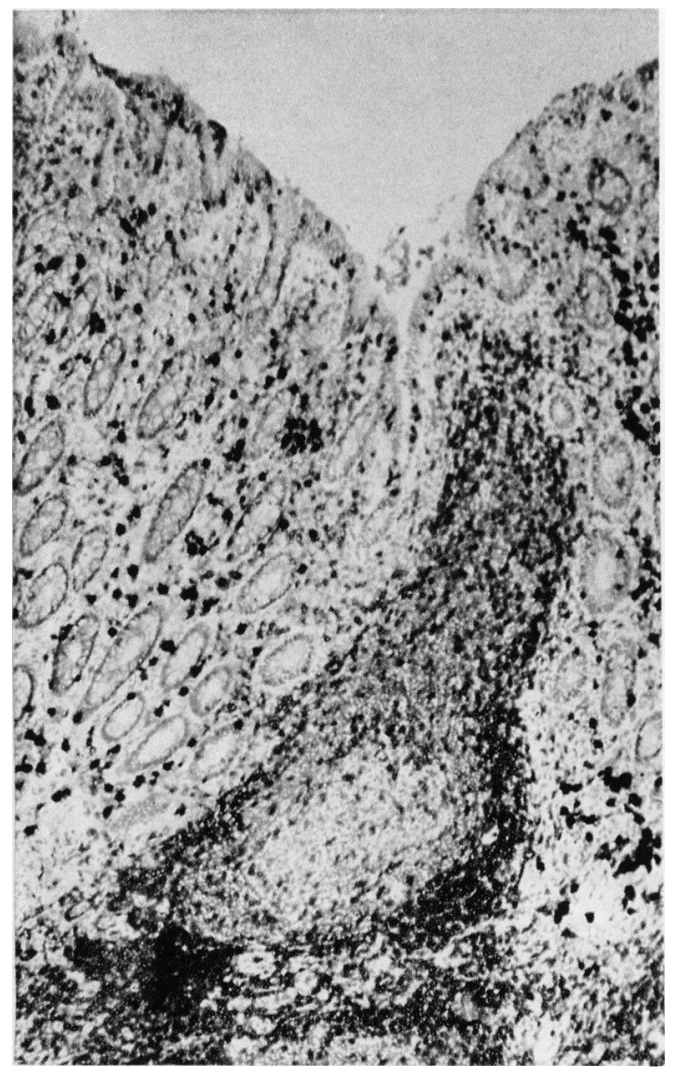

Fig. 4

Fig. 4 Cryostat section of appendix stained with pan $T$-cell monoclonal antibody. A rim of T-cell can be seen around the lymphoid nodule merging with a sheet of $T$-cells below. Intra-epithelial $T$-cells are evident. The large, darkly-staining cells are predominently eosinophils which contain endogenous peroxidase. Immunoperoxidase $\times 100$.

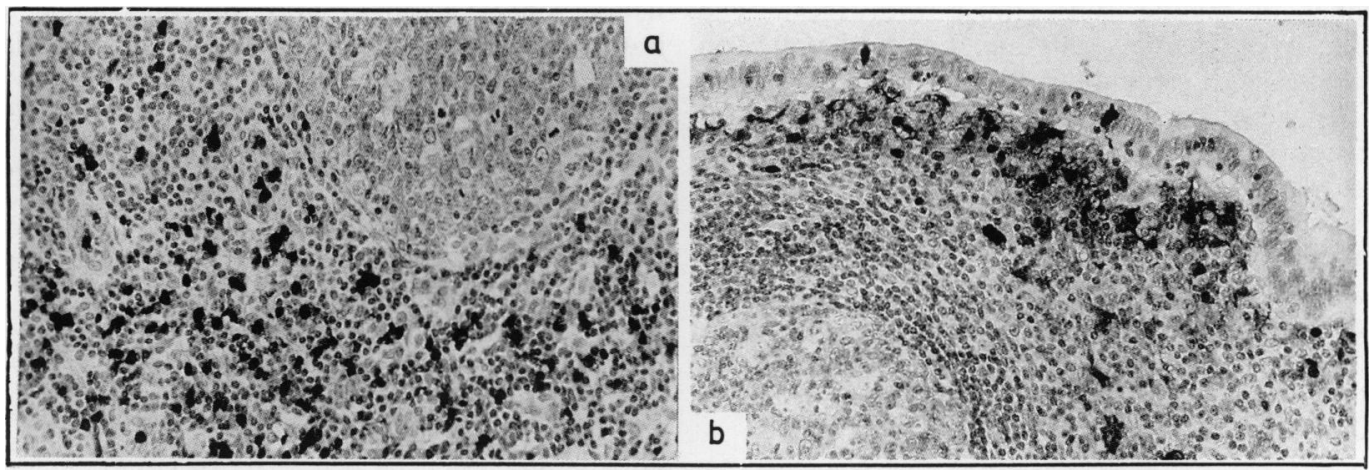

Fig. 5 Paraffin section of appendix stained with antibody to $S$-100 protein. (a) $T$-cell zone beneath follicle centre showing positively staining cells lacking cytoplasmic processes in contrast to (b) which shows $S$-100-positive macrophages beneath the surface epithelium with clearly evident cytoplasmic processes. Note occasional positive cell within the epithelium. Immunoperoxidase $\times 250$. 


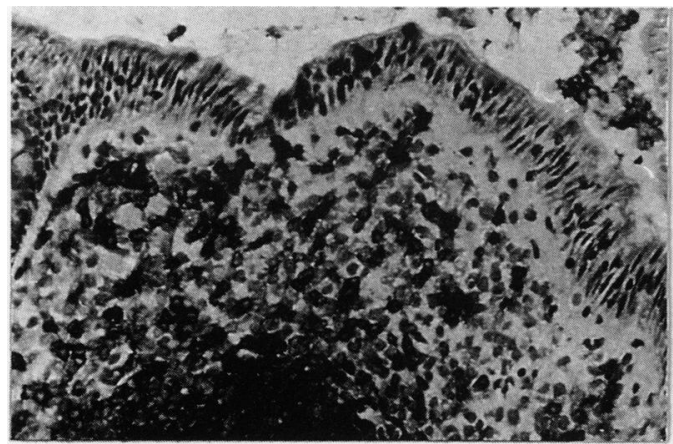

Fig. 6

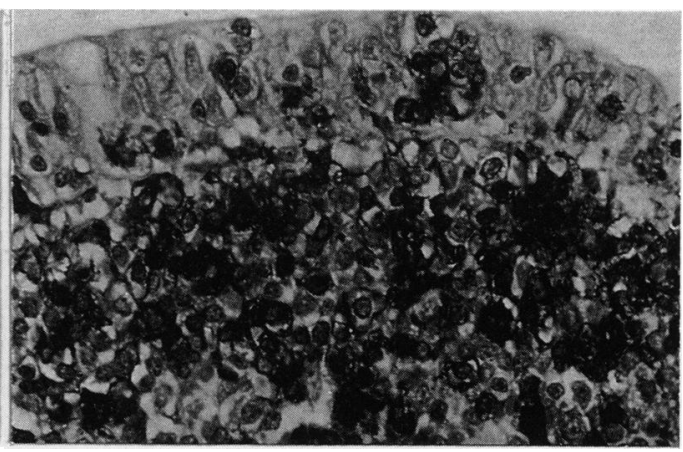

Fig. 7

Fig. 6 Cryostat section of mixed cell zone and dome epithelium stained with a monoclonal antibody to B-cells. The edge of the mantle zone can be seen at the bottom of the illustration and numerous $B$-cells are evident in the mixed cell zone. $A$ cluster of intra-epithelial B-cells is evident. Note the absence of B-cells in the crypt epithelium. Immunoperoxidase $\times 400$.

Fig. 7 Paraffin section of mixed cell zone and dome epithelium of appendix stained with monoclonal antibody to HLA $D R$. Numerous HLA DR-positive cells (macrophages and.B-cells) are present in the mixed cell zone and in the epithelium. Immunoperoxidase $\times 1000$.

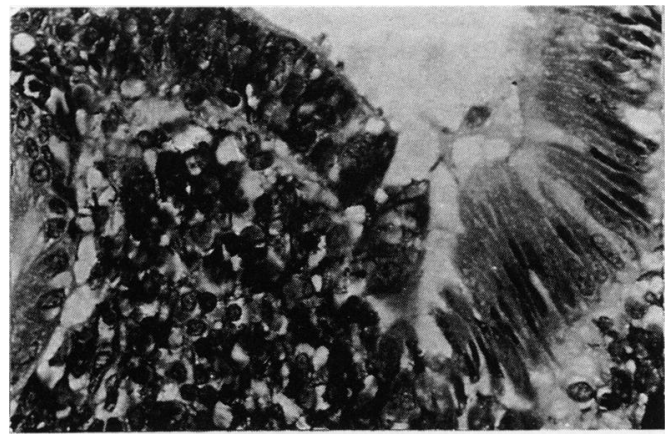

Fig. 8 Paraffin section of appendix stained with the monoclonal antibody to HLA DR showing mixed cell zone and dome epithelium (left) and crypt epithelium (right). HLA DR-positive epithelial cells are present in the dome but not in the crypt epithelium. Immunoperoxidase $\times 1000$.

lymphoid tissue in the human appendix reveal as expected close similarities to peripheral lymphoid tissue. ${ }^{8}$ An equivalent of the mixed cell zone has not, however, been described in peripheral lymphoid tissue and the lymphoepithelium which forms the dome of the follicle has not previously been immunohistochemically defined in human gut.

Faulk et $a^{12}$ identified the mixed cell zone in their morphological studies of the rabbit appendix. Our studies have shown that in humans the mixed cell zone is composed of many B-cells, some of which are mantle zone cells, T-cells and HLA DRpositive, S-100-positive macrophages. Few macrophages stain for lysozyme. The results using antiHLA DR in paraffin sections show that some of the HLA DR-positive cells are morphologically similar to centrocytes and it is possible that these cells are among those recognised by the anti-B-cell anti- serum. Another possibility is that these cells are equivalent to the marginal zone B-cells in the spleen. ${ }^{13}$ The mixed cell zone of the appendix does indeed bear a strong morphological resemblance to the splenic marginal zone (unpublished observations).

The presence of intraepithelial B-lymphocytes in dome epithelium of human gut associated lymphoid tissue has not been previously shown immunohistochemically. In in vivo pulse radiolabelling experiments Faulk et al ${ }^{12}$ showed the migration of dividing lymphocytes (presumably B-cells) from the follicle centre to the epithelium in rabbit appendix. More recently Owen and coworkers have shown in ultrastructural studies that intraepithelial lymphocytes are present in the dome epithelium in increased numbers compared with the crypts and that they share morphological properties with follicle 
Table 3 Summary of results

\begin{tabular}{|c|c|c|c|c|}
\hline & Plasma cells & B-lymphocytes & T-lymphocytes & Macrophages \\
\hline Lamina propria & $(+++)$ & $(-)$ & $(+)$ & $\begin{array}{l}(++) \\
\text { lysozyme positive } \\
\text { HLA DR positive } \\
\text { S-100 positive (with } \\
\text { cytoplasmic processes) }\end{array}$ \\
\hline $\begin{array}{l}\text { Lymphoid tissue } \\
\text { between follicles and } \\
\text { muscularis mucosae }\end{array}$ & $(-)$ & $(-)$ & $(+++)$ & $\begin{array}{l}(+) \\
\text { S-100 positive (no obvious } \\
\text { cytoplasmic processes) } \\
\text { HLA DR positive }\end{array}$ \\
\hline Follicular mantle cells & $(-)$ & $\begin{array}{l}(+++) \\
\text { slgD positive } \\
\text { slgM positive } \\
\text { HLA DR positive }\end{array}$ & $(+)$ & $\begin{array}{l}(+) \\
\text { HLA DR positive }\end{array}$ \\
\hline Follicle centres & $(-)$ & $\begin{array}{l}(+++) \\
\text { HLA DR positive } \\
\text { centrocytes and } \\
\text { centroblasts }\end{array}$ & $(+)$ & $\begin{array}{l}(++) \\
\text { HLA DR positive }\end{array}$ \\
\hline Mixed cell zone & $(-)$ & $\begin{array}{l}(++) \\
\text { HLA DR positive } \\
\text { centrocyte-like }\end{array}$ & $(++)$ & $\begin{array}{l}(++) \\
\text { HLA DR positive } \\
\text { S-100 positive } \\
\text { Few lysozyme positive }\end{array}$ \\
\hline \multirow{2}{*}{$\begin{array}{l}\text { Crypt epithelium } \\
\text { Dome epithelium }\end{array}$} & $(-)$ & $(-)$ & $(+)$ & $(-)$ \\
\hline & $(-)$ & $\begin{array}{l}(+) \\
\text { HLA DR positive } \\
\text { centrocyte-like }\end{array}$ & $(+)$ & $\begin{array}{l}(+/-) \\
\text { HLA DR positive } \\
\text { lysozyme positive }\end{array}$ \\
\hline $\begin{array}{ll}(-) & \text { Absent } \\
(+/-) & \text { Occasion } \\
(+) & \\
(++) & \\
(+++) & \text { Increasin }\end{array}$ & $\begin{array}{l}\text { Absent } \\
\text { Occasionally present } \\
\text { Increasing abundance }\end{array}$ & & & \\
\hline
\end{tabular}

centre cells. ${ }^{14}{ }^{15}$ It is possible, therefore, that these centrocyte-like cells in the dome epithelium may be immediately derived from the follicle centre, and the equivalent cells in the mixed cell zone may be these same cells in transit.

Further support for the follicle centre cell-like nature of dome IE B-cells comes from studies of gastrointestinal lymphoma of follicle centre cell origin. These tumours are characterised by the formation of lymphoepithelial lesions formed by malignant follicle centre cells specifically invading glandular epithelium. ${ }^{16}$ These lesions are not seen in gastrointestinal lymphomas of other histogenetic type.$^{17}$ It is conceivable that this lymphoepithelial lesion is a parody of the normal B-cell lymphoepithelial relationships that we have shown.

The relevance of our findings to immunological function is a matter for conjecture. The intimate association of HLA DR-positive macrophages Blymphocytes and T-cells in the mixed cell zone suggests that this is likely to be the site where antigen transported from the gut lumen by M-cells ${ }^{18}$ encounters the cells responsible for the immune response. The presence of intraepithelial B-cells in the dome may relate to the acquisition of homing properties of the B-cells derived from gut associated lymphoid tissue. It has been shown by Butcher $e t$ $a l^{19}$ that follicle centre cells in gut associated lymphoid tissue lack the specific homing properties shown by more mature immunoblasts. ${ }^{20} 21$ It is conceivable that the intraepithelial B-cells migrate to this site from the follicle centre in order to acquire the necessary information for homing to the gut before embarking on their journey through the intestinal lymphatics and the bloodstream en route to the intestinal lamina propria. This would be consistent with the 'instructive hypothesis' proposed by Phillips-Quagliata. ${ }^{22}$

The complex and distinctive properties of the mucosal lymphoid nodules shown by this study suggest that careful analysis of these structures in immune-related gastrointestinal disease may be more profitable than regarding the mucosa as a single unit.

We would like to thank Margaret Squire for typing this manuscript. This work was supported by MRC Grant G8222346 CA. 


\section{References}

1 Bienenstock J, Befus AD. Review: mucosal immunology. Immunology 1980; 41: 249-70.

2 Selby WS, Janossy G, Jewell DP. Immunohistological characterisation of intraepithelial lymphocytes of the human gastrointestinal tract. Gut 1981; 22: 169-76.

3 André C, André F, Fargier MC. Distribution of $\operatorname{IgA}_{1}$ and $\mathrm{IgA}_{2}$ plasma cells in various normal human tissues and in the jejunum of plasma $\operatorname{IgA}$-deficient patients. Clin Exp Immunol 1978; 33: 327-31.

4 Selby WS, Poulter LW, Hobbs S, Jewell DP, Janossy G. Heterogeneity of HLA DR-positive histiocytes in human intestinal lamina propria: a combined histochemical and immunohistochemical analysis. J Clin Pathol 1983; 36: 379-84.

5 Lennert K. Follicular lymphoma. A tumour of the germinal centres. In: Akazaki $\mathrm{K}$, Rappaport $\mathrm{H}$, Bernard CW, Bennet JM, Ishikawa E, eds. Malignant diseases of the hematopoietic system. GANN Monograph on Cancer Research, No. 15. Tokyo: University of Tokyo Press, 1973, 217-31.

6 Lukes RJ, Collins RD. New observations in follicular lymphoma. In: Akazaki K, et al, eds. Malignant diseases of the hematopoietic system. GANN Monograph on Cancer Research, No. 15. Tokyo: University of Tokyo Press, 1973, 209-15.

7 Stein H, Gerdes J, Mason DY. The normal and malignant germinal centre. Clin Haematol 1982; 11: 531-59.

8 Stein H, Bonk A, Tolksdorf G, Lennert K, Rodt H, Gerdes J. Immunohistologic analysis of the organisation of normal lymphoid tissue and non-Hodgkin's lymphomas. J Histochem Cytochem 1980; 28: 746-60.

9 Curran RC, Gregory J. Effects of fixation and processing on immunohistochemical demonstration of immunoglobulin in paraffin sections of tonsil and bone marrow. J Clin Pathol 1980; 33: 1047-57.

10 Isaacson $\mathrm{P}$, Wright $\mathrm{DH}$. Immunocytochemistry of lymphoreticular tumours. In: Polak JM, Van Noorden S, eds. Practical applications in pathology and biology. Bristol: John Wright, 1983: 249-73:

11 Graham RC, Karnovsky MJ. The early stages of absorption of injected horse radish peroxidase into the proximal tubules of mouse kidney: ultrastructural cytochemistry by a new technique. J Histochem Cytochem 1966; 14: 291-302.

12 Faulk WP, McCormick JN, Goodman JR, Yoffey JM, Fudenberg HH. Peyer's patches: morphologic studies. Cell Immunol 1971; 1: 500-20.

13 Kumaratne DS, Bazin H, MacLennan ICM. Marginal zones: the major B cell compartment of rat spleens. Eur J Immunol 1981; 11: 858-64.

14 Owen RL, Jones AL. Epithelial cells specialisation within human Peyer's patches: an ultrastructural study of intestinal lymphoid follicles. Gastroenterology 1974; 66: 189-203.

15 Bhalla DK, Owen RL. Cell renewal and migration in lymphoid follicles of Peyer's patch and cecum - an autoradiographic study in mice. Gastroenterology 1982; 82: 232-42.

16 Isaacson PG, Wright DH. Malignant lymphoma of mucosa-associated lymphoid tissue: a distinctive type of B-cell lymphoma. Cancer 1983; 52: 1410-6.

17 Isaacson PG, MacLennan KA, Subbuswamy SG. Multiple lymphomatous polyposis of the gastrointestinal tract. Histopathology 1984; 8: 641-56.

18 Owen RL. Sequential uptake of horseradish peroxidase by lymphoid follicle epithelium of Peyers' patches in the normal unobstructed mouse intestine: an ultrastructural study. Gastroenterology 1977; 72: 440-51.

19 Butcher EC, Stevens SK, Reichert RA, Scollay RG, Weissman IL. Lymphocyte-endothelial cell recognition in lymphocyte migration and the segregation of mucosal and non-mucosal immunity. In: Strober W, Hanson LA, Sell KW, eds. Recent advances in mucosal immunity. Raven Press: New York, 1982: 3-24.

20 Gowans JL, Knight EJ. The route of recirculation of lymphocytes in the rat. Proc R Soc Lond [Biol] 1964; 159: $257-82$.

21 Hall JG, Parry DM, Smith ME. The distribution and differentiation of lymph-borne immunoblasts after intravenous injection into syngeneic recipients. Cell Tissue Kinet 1972; 5: 269-81.

22 Phillips-Quagliata JM, Roux ME, Arny M, KellyHatfield P, McWilliams M, Lamm ME. Migration and regulation of B-cells in the mucosal immune system. The secretory immune system. Ann NY Acad Sci 1983; 409: 194-203. 